\title{
PRESTASI BELAJAR MATEMATIKA DITINJAU DARI SIKAP DAN KOMITMEN DIRI PESERTA DIDIK PADA PELAJARAN MATEMATIKA
}

\author{
Arif Rahman Hakim \\ Program Studi Pendidikan Matematika, \\ FTMIPA, Universitas Indraprasta PGRI Jakarta. \\ e-mail: arsyanriftyrahman@gmail.com
}

\begin{abstract}
Abstrak: Prestasi Belajar Matematika Ditinjau dari Sikap dan Komitmen Diri Peserta Didik pada Pelajaran Matematika. Penelitian ini bertujuan untuk mengetahui pengaruh simultan sikap dan komitmen diri peserta didik terhadap prestasi belajar matematika, untuk mengetahui pengaruh sikap peserta didik terhadap prestasi belajar matematika, dan untuk mengetahui pengaruh komitmen diri peserta didik terhadap prestasi belajar matematika. Penelitian ini adalah penelitian survai pada peserta didik kelas VII di Panglima Besar Soedirman International Islamic Junior High School (PBS-IIJHS). Sampel dalam penelitian ini berjumlah 67 orang peserta didik yang diambil dengan cara random dari populasi terjangkau sebanyak 207 orang peserta didik. Instrumen yang digunakan dalam penelitian ini adalah dengan teknik tes tulis dalam bentuk soal multiple choice dan essay, serta teknik nontes dalam bentuk kuesioner yang terlebih dahulu divalidasi secara empiris. Analisis data dilakukan secara deskriptif dan secara inferensial yang terlebih dahulu menguji persyaratan analisis, yaitu uji normalitas, uji linearitas, dan uji multikolinearitas. Berdasarkan hasil penelitian, diperoleh simpulan bahwa terdapat pengaruh yang signifikan sikap dan komitmen diri peserta didik secara bersama-sama terhadap prestasi belajar matematika. Kemudian terdapat pengaruh yang signifikan sikap peserta didik terhadap prestasi belajar matematika. Serta terdapat pengaruh yang signifikan komitmen diri peserta didik terhadap prestasi belajar matematika.
\end{abstract}

\section{Kata Kunci: Prestasi Belajar Matematika, Sikap, Komitmen Diri.}

\begin{abstract}
Judging from the Mathematics Learning Achievement Attitude and Commitment Task Learners in Math Lessons. This study aims to determine the effect of simultaneous attitude and commitment to self-learners towards mathematics achievement, to determine the influence of attitudes of students towards mathematics achievement, and to determine the effect of personal commitment to the achievement of learners studying mathematics. This research is a survey among students of class VII in Panglima Besar Soedirman International Islamic Junior High School (PBS-IIJHS). The sample in this study amounted to 67 learners were taken by random from a population of as many as 207 people affordadle learners. Instruments used in this research is by using a written test in the form of multiple choice questions and essays, as well as non test technique in the form of qoestionnaires which prior validated empirically. The data were analyzed descriptively and inferentially that prior testing its requirements analisis; the normality test, linearity and multicollinearity test. Based on the research results, it can be concluded that there is a significant influence between attitudes and self-learners commitment toward mathematics achievement. Then there is a significant influence learners' attitudes toward mathematics achievement. As well as a significant influence learners' commitment toward mathematics achievement.
\end{abstract}

Keywords: Mathematics Learning Achievement, Attitude, Commitment Task. 


\section{PENDAHULUAN}

Konseptualisasi yang baik atas pendidikan akan jauh lebih baik dalam upaya meningkatkan tumbuh kembang pembangunan bangsa dan negara. Hal ini disebabkan karena tumbuh kembang pembangunan pada suatu bangsa dan negara yang dinamis senantiasa didorong oleh bidang pendidikan. Bidang pendidikan dapat menjadi penopang dalam hal membangun suatu peradaban, sekaligus membangun sumber daya manusia yang unggul sebagai motor penggerak pembangunan bangsa dan negara.

Membangun sumber daya manusia yang unggul melalui bidang pendidikan bukanlah sebuah mitos dalam cerita dongeng. Bidang pendidikan seyogyanya dapat melaksanakan fungsi dengan sebaikbaiknya, yakni "mengembangkan kemampuan dan membentuk watak serta peradaban bangsa yang bermartabat dalam rangka mencerdaskan kehidupan bangsa". Adapun secara konkret, fungsi pendidikan ini dapat terpenuhi dengan suatu kegiatan pembelajaran. Pembelajaran menjadi bingkai dalam hal "berkembangnya potensi peserta didik", sehingga peserta didik dapat tumbuh menjadi pribadi yang baik dengan watak yang kuat untuk membangun peradaban bangsa.

Pembelajaran adalah proses interaksi peserta didik dengan pendidik dan sumber belajar pada suatu lingkungan belajar. Setiap kegiatan pembelajaran menuntut peserta didik untuk memberikan prestasi-prestasi tertentu untuk menampakkan hasil belajar secara nyata dan relevan bagi tujuan instruksional. Prestasi diperlukan untuk mengetahui apakah tujuan yang diharapkan dapat dicapai atau tidak. Kegiatan pembelajaran pada jenjang pendidikan dasar dan menengah terlaksana untuk setiap mata pelajaran, termasuk mata pelajaran Matematika. Dengan demikian, tercapai atau tidaknya tujuan instruksional pada mata pelajaran Matematika dapat terlihat dari prestasi belajar matematika dari peserta didik. Atau dengan kata lain, prestasi belajar matematika menjadi sebuah bukti atas keberhasilan dalam kegiatan belajar matematika yang dilaksanakan oleh peserta didik.

Saat ini, prestasi belajar matematika bagi peserta didik secara umum di Indonesia sudah baik dan sangat membanggakan. Prestasi belajar matematika bagi peserta didik sudah mulai merangsek naik dan cenderung membanggakan, baik di level nasional, regional, maupun global. Hal ini dapat dilihat dari peserta didik asal Indonesia yang meraih medali di olimpiade matematika tingkat internasional, seperti medali emas pada event Thailand International Mathematics Competition (TIMC) 2016 yang berlangsung pada 14 s.d. 20 Agustus 2016 di Chiang Mai, Thailand. Pada event tersebut, peserta dari Indonesia meraih 1 medali emas, 3 medali perak, dan 4 medali perunggu (Puspitasari, 2016). Pada event lain yang bertajuk World Mathematics Competition ke-13, peserta didik asal Indonesia meraih medali emas (Metropolis, 2016). Ada juga prestasi meraih medali emas dalam ajang tahunan bertajuk International Mathematics Competition (IMC) yang digelar di Singapura pada 30 Juli 2016 (Baiquni, 2016).

Beragam prestasi membanggakan dari peserta didik pada bidang Matematika tentunya tidak sekadar datang begitu saja. Banyak faktor yang menjadikan peserta didik memeroleh sejumlah prestasi gemilang tersebut, diantaranya minat dan motivasi belajar yang tinggi, disiplin dalam belajar, komitmen diri untuk tekun belajar, 
sikap suka pada matematika dan menghargai berbagai hal tentang matematika, dan lain-lain. Sikap peserta didik pada mata pelajaran matematika menjadi salah satu faktor tercapainya prestasi belajar matematika yang baik bagi seorang peserta didik. Umumnya peserta didik yang suka pada mata pelajaran matematika akan jauh lebih baik prestasinya daripada peserta didik yang biasa saja atau bahkan dari peserta didik yang tidak suka pada pelajaran matematika.

Sikap yang baik dari peserta didik pada mata pelajaran matematika seyogyanya dapat dibangun secara continue setiap saat dimana peserta didik mengikuti kegiatan rutin belajar matematika. Adapun komponen sikap yang mesti dibangun antara lain: (1) Komponen Kognitif, yaitu segmen kesadaran opini atau keyakinan dari sikap (2) Komponen Afektif, yaitu segmen emosional atau perasaan dari sikap; dan (3) Komponen Perilaku, yaitu segmen niat untuk berperilaku dalam cara tertentu terhadap seseorang atau sesuatu (Robbins dan Timothy, 2008: 93). Peserta didik dengan kualitas sikap yang baik biasanya memiliki opini positif pada matematika, suka dan antusias mengikuti seluruh rangkaian kegiatan belajar matematika, juga memang niat yang kuat untuk memahami substansi kajian matematika dengan sebaik-baiknya.

Tentang sikap peserta didik pada pelajaran matematika berpengaruh positif dan signifikan disampaikan oleh beberapa orang peneliti melalui hasil penelitian yang sudah dilaksanakannya. Hartati (2013) menyatakan bahwa siswa yang memiliki sikap positif pada pelajaran matematika cenderung mendapatkan hasil belajar yang baik, sementara siswa yang memiliki sikap negatif pada pelajaran matematika cenderung kurang memuaskan. Hartati juga menyebutkan bahwa hasil belajar matematika siswa yang memiliki sikap positif pada pelajaran matematika lebih tinggi daripada hasil belajar siswa yang memiliki sikap negatif pada pelajaran matematika. Selain Hartati, Karim (2014) melalui hasil penelitiannya menyatakan bahwa sikap peserta didik pada pelajaran matematika harus positif, karena dengan sikap positif dari peserta didik pada pelajaran matematika akan menjadikan hasil yang baik atas kegiatan belajar matematika. Kemudian, Hakim (2015) menyatakan bahwa prestasi belajar matematika dipengaruhi secara signifikan oleh sikap peserta didik pada pelajaran matematika. Hakim (2015) juga menyatakan bahwasanya guru seyogyanya dapat membangun segenap perilaku sikap yang baik dari peserta didik atas kegiatan belajar matematika.

\section{METODE}

Penelitian ini dilaksanakan pada peserta didik kelas VII di Panglima Besar Soedirman International Islamic Junior High School (PBS-IIJHS), Cijantung, Jakarta Timur. Sekolah ini secara tepat beralamat di Jln. Raya Bogor KM.24, Cijantung, Jakarta Timur. Penelitian yang dilaksanakan pada bulan September s.d. Oktober di tahun 2016 ini merupakan penelitian survai korelasional dengan analisis regresi ganda. Adapun desain penelitian digambarkan sebagai berikut:

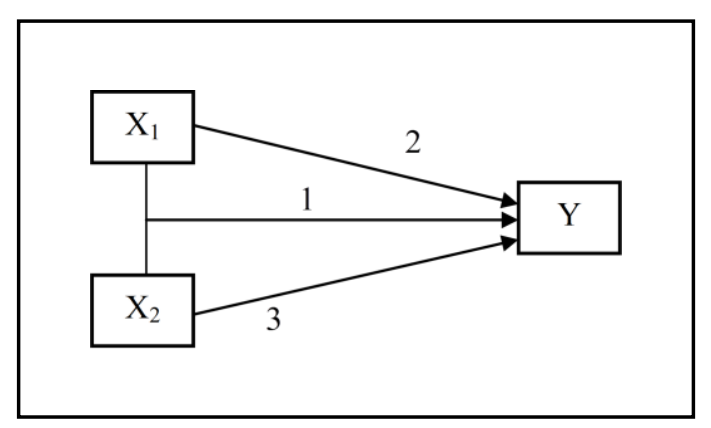

Gambar 1. Desain Penelitian 
Keterangan:

$\mathrm{X}_{1}$ : Sikap Peserta Didik

$\mathrm{X}_{2}$ : Komitmen Diri Peserta Didik

$\mathrm{Y}$ : Prestasi Belajar Matematika

1 : Pengaruh Sikap dan Komitmen

Diri Peserta Didik Secara

Bersama-sama terhadap Prestasi

Belajar Matematika

2 : Pengaruh Sikap Peserta Didik terhadap Prestasi Belajar

Matematika

3 : Pengaruh Komitmen Diri

Peserta Didik terhadap Prestasi

Belajar Matematika

Populasi target dari penelitian ini adalah seluruh peserta didik di Panglima Besar Soedirman International Islamic Junior High School (PBS-IIJHS) pada tahun pelajaran 2016/2017. Adapun Populasi terjangkau dari penelitian ini adalah seluruh peserta didik kelas VII di Panglima Besar Soedirman International Islamic Junior High School (PBS-IIJHS) yang berjumlah 207 orang peserta didik yang terbagi menjadi tujuh kelas paralel atau tujuh rombongan belajar. Pengambilan sampel penelitian dipilih secara acak sederhana atau simple random sampling. Setelah pengundian, sampel yang digunakan dalam penelitian ini adalah 67 orang peserta didik yang mana teknik menentukan jumlah sampel penelitian dengan menggunakan rumus dari Taro Yamane (Riduwan, 2006: 65).

Perangkat instrumen pada penelitian ini terdiri dari instrumen bentuk tes dan nontes. Instrumen tes digunakan untuk variabel prestasi belajar matematika dan instrumen nontes digunakan untuk variabel sikap dan komitmen diri. Instrumen penelitian divalidasi secara empiris, dimana instrumen diujicobakan kepada 30 orang peserta didik yang tidak masuk dalam sampel penelitian.
Pengembangan instrumen prestasi belajar matematika berupa instrumen tes tulis dalam bentuk pilihan ganda dan essai. Untuk soal tes bentuk pilihan ganda terdiri dari 25 butir soal dengan 4 alternatif pilihan jawaban dan untuk soal tes bentuk essai terdiri dari 5 butir soal. Perangkat instrumen tersebut semuanya masuk dalam pokok bahasan aljabar, himpunan dan aritmatika sosial. Sebanyak 25 butir soal bentuk pilihan ganda dan 5 butir soal essai yang disiapkan dan digunakan sebagai sumber pengambilan data untuk hasil belajar matematika peserta didik. Pengembangan instrumen sikap berupa angket yang mana semua butir pernyataannya masuk dalam komponen sikap yang disampaikan oleh Robbins dan Timothy (2008: 93) yaitu: "tiga komponen sikap antara lain: (1) Komponen Kognitif, yaitu segmen kesadaran opini atau keyakinan dari sikap (2) Komponen Afektif, yaitu segmen emosional atau perasaan dari sikap; dan (3) Komponen Perilaku, yaitu segmen niat untuk berperilaku dalam cara tertentu terhadap seseorang atau sesuatu". Pengembangan instrumen komitmen diri berupa angket yang mana semua butir pernyataannya masuk dalam aspek task commitment yang disampaikan oleh Renzulli yaitu beberapa aspek yang terdapat pada task commitment (komitmen terhadap tugas), antara lain: (1) Mengidentifikasi Masalah; (2) Menentukan Pilihan; dan (3) Menentukan Standar.

Teknik analisis terhadap data hasil penelitian yang dalam hal ini berupa nilai prestasi belajar matematika serta perolehan total skor atas angket sikap dan komitmen diri peserta didik dilakukan secara deskriptif dan inferensial. Secara deskriptif, data hasil penelitian dianalisis untuk skor mean, median, dan modus. Adapun maksud analisis skor mean, median, dan modus 
adalah untuk mendeskripsikan ukuran pemusatan data dari subjek penelitian. Secara inferensial, data hasil penelitian dianalisis dengan uji $\boldsymbol{F}$ dan uji $\boldsymbol{t}$, dengan terlebih dahulu diuji untuk persyaratannya yaitu uji normalitas, uji linearitas, dan uji multikolinearitas. Perhitungan data hasil penelitian dilakukan dengan menggunakan bantuan software SPSS.

\section{HASIL DAN PEMBAHASAN}

\section{Hasil Penelitian}

Hasil penelitian untuk 76 responden yang secara umur berada di usia sekitar 12 s.d. 13 tahun. Data hasil penelitian ini dianalisis secara deskriptif dan inferensial, dimana secara deskriptif, data hasil penelitian ini ditampilkan dalam tabel 1 .

Tabel 1. Ringkasan Hasil Perhitungan Statistik Deskriptif

\begin{tabular}{lcccc}
\hline \multicolumn{1}{c}{ Kelompok } & Resp. & Mean & Median & Modus \\
\hline Prestasi Belajar Matematika & 67 & 59,63 & 60,00 & 47,00 \\
Sikap Peserta Didik & 67 & 68,10 & 69,00 & 65,00 \\
Komitmen Diri Peserta Didik & 67 & 63,13 & 63,00 & 63,00 \\
\hline
\end{tabular}

Sumber: Data primer yang diolah

Berdasarkan tabel 1, diperoleh informasi untuk variabel prestasi belajar matematika peserta didik bahwa skor mean, median, dan modus relatif sama yang berada di satu titik yakni kisaran angka 75. Hal ini berarti, kurva distribusi frekuensi akan terbentuk simetris, yang maknanya adalah frekuensi dari skor prestasi belajar matematika peserta didik yang tinggi dan rendah relatif sama. Kemudian berdasarkan tabel 1 juga, dapat diperoleh informasi bahwa skor mean, median, dan modus untuk variabel sikap peserta didik tidaklah sama, dimana skor mean lebih kecil dari skor median, dan skor median lebih kecil dari skor modus. Hal ini berarti, kurva distribusi frekuensi akan terbentuk miring ke kiri, yang maknanya adalah akan ada frekuensi lebih rendah dari skor sikap peserta didik yang tinggi dan frekuensi lebih tinggi dari skor sikap peserta didik yang rendah. Informasi terakhir berdasarkan tabel 1 juga diperoleh bahwa skor mean, median, dan modus untuk variabel komitmen diri peserta didik pada pelajaran matematika tidaklah sama, dimana skor mean lebih kecil dari skor median, dan skor median lebih kecil dari skor modus. Hal ini juga berarti, kurva distribusi frekuansi komitmen diri peserta didik pada pelajaran matematika akan terbentuk miring ke kiri, yang maknanya adalah akan ada frekuensi lebih rendah dari skor tinggi untuk komitmen diri peserta didik pada pelajaran matematika dan frekuensi lebih tinggi dari skor rendah komitmen diri peserta didik pada pelajaran matematika.

Selanjutnya data hasil penelitian dianalisis secara inferensial untuk pengujian hipotesis, namun terlebih dahulu harus dilakukan uji persyaratan analisis data, yang meliputi uji normalitas, uji linearitas, dan uji multikolinearitas. Pengujian normalitas dilakukan untuk mengetahui normal atau tidaknya distribusi data yang akan dianalisis. Perhitungan untuk uji normalitas data dilakukan dengan uji Kolmogorof Smirnof. Kriteria pengujiannya adalah jika nilai probabilitas atau asymp. sig. (2-tailed) $>0,05$ (karena dalam penelitian ini 
menggunakan $\alpha=5 \%$, maka dinyatakan data berasal dari populasi berdistribusi normal. Berdasarkan tabel 2, terlihat bahwa kelompok sampel yang diteliti memiliki nilai probabilitas atau asymp. sig. (2-tailed) $>0,05$, sehingga dapat disimpulkan bahwasanya data yang diperoleh dari ketiga variabel dalam penelitian ini berasal dari populasi yang berdistribusi normal.

Tabel 2. Ringkasan Hasil Uji Normalitas

\begin{tabular}{lcc}
\hline \multicolumn{1}{c}{ Variabel } & $\begin{array}{c}\text { Kolmogorov- } \\
\text { Smirnov Z }\end{array}$ & $\begin{array}{c}\text { Asymp. Sig. } \\
\text { (2-tailed) }\end{array}$ \\
\hline Prestasi Belajar Matematika & 0,665 & 0,769 \\
Sikap Peserta Didik & 0,594 & 0,872 \\
Komitmen Diri Peserta Didik & 0,929 & 0,354 \\
\hline
\end{tabular}

Sumber: Data primer yang diolah

Setelah uji normalitas data, selanjutnya dilakukan uji persyaratan analisis untuk uji linearitas. Pengujian linearitas dimaksudkan untuk mengetahui apakah dua variabel berpola linear antara satu sama lainnya. Dengan kata lain, uji linearitas dilakukan dalam rangka menguji model persamaan suatu variabel terikat atas suatu variabel bebas. Kriteria pengujiannya adalah kedua variabel dikatakan berpola linear jika nilai sig. linearity $<0,05$ (dalam penelitian ini menggunakan $\alpha=5 \%$ ). Oleh karena pada penelitian ini terdapat satu variabel terikat (Y) dan dua variabel bebas $\left(\mathrm{X}_{1}\right.$ dan $\left.\mathrm{X}_{2}\right)$, maka ada dua uji linearitas. Pertama uji linearitas $\mathrm{X}_{1}$ terhadap $\mathrm{Y}$, yang mana berdasarkan tabel 3, terlihat bahwa nilai sig. linearity $<0,05$, sehingga dapat disimpulkan bahwa terdapat hubungan yang linear antara sikap peserta didik pada pelajaran matematika $\left(\mathrm{X}_{1}\right)$ dengan prestasi belajar matematika (Y). Yang kedua uji linearitas $\mathrm{X}_{2}$ terhadap $\mathrm{Y}$, yang mana berdasarkan tabel 4, terlihat bahwa nilai sig. linearity $<0,05$, sehingga dapat disimpulkan bahwa terdapat hubungan yang linear antara komitmen diri peserta didik pada pelajaran matematika $\left(\mathrm{X}_{2}\right)$ dengan prestasi belajar matematika $(\mathrm{Y})$.

Tabel 3. Ringkasan Hasil Uji Linearitas Sikap Peserta Didik terhadap Prestasi Belajar Matematika

\begin{tabular}{llccccc}
\hline & Model & Sum of Squares & $d f$ & Mean Square & $F$ & Sig. \\
\hline 1 & Regression & 1675,827 & 1 & 1675,827 & 16,852 & 0,000 \\
& Residual & 6463,845 & 65 & 99,444 & & \\
& Total & 8139,672 & 66 & & & \\
\hline
\end{tabular}

Sumber: Data primer yang diolah

Tabel 4. Ringkasan Hasil Uji Linearitas Komitmen Diri Peserta Didik terhadap Prestasi Belajar Matematika

\begin{tabular}{llccccc}
\hline & Model & Sum of Squares & $d f$ & Mean Square & $F$ & Sig. \\
\hline 1 & Regression & 1653,302 & 1 & 1653,302 & 16,568 & 0,000 \\
& Residual & 6486,370 & 65 & 99,790 & & \\
& Total & 8139,672 & 66 & & & \\
\hline
\end{tabular}

Sumber: Data primer yang diolah 
Setelah uji linearitas terpenuhi, selanjutnya dilakukan uji persyaratan yang terakhir yaitu uji multikolinearitas. Uji multikolinearitas dimaksudkan untuk mengetahui hubungan antar variabel bebas yaitu ada atau tidaknya hubungan yang kuat antara variabel sikap peserta didik pada pelajaran matematika dengan komitmen diri peserta didik pada pelajaran matematika. Kriteria pengujiannya adalah kedua variabel bebas tidak terdapat masalah multikolinearitas jika nilai Variance Inflation Factor (VIF) < 10. Berdasarkan tabel 5, terlihat bahwa nilai Variance Inflation Factor (VIF) < 10 , berarti variabel terbebas dari asumsi klasik multikolinearitas atau dengan kata lain kedua variabel bebas tidak terdapat masalah multikolinearitas.

Tabel 5. Ringkasan Hasil Uji Multikolinearitas

\begin{tabular}{llcc}
\hline \multicolumn{2}{l}{ Model } & \multicolumn{2}{c}{ Collinearity Statistics } \\
\hline 1 & Sikap & Tolerance & VIF \\
\hline & Komitmen & 0,525 & 1,906 \\
\end{tabular}

Sumber: Data primer yang diolah

Setelah semua uji persyaratan analisis terpenuhi, dilanjutkan dengan pengujian hipotesis, yaitu uji pengaruh sikap dan komitmen diri peserta didik secara bersama-sama terhadap prestasi belajar matematika, uji pengaruh sikap peserta didik terhadap prestasi belajar matematika, dan uji pengaruh komitmen diri peserta didik terhadap prestasi belajar matematika. Secara keseluruhan, pengujian ketiga hipotesis dalam penelitian ini dijawab oleh tiga tabel ringkasan hasil perhitungan. Tabel 6 menunjukkan nilai korelasi ganda dan besarnya nilai korelasi ganda setelah dikuadratkan. Kemudian tabel 7 menunjukkan besarnya nilai $F_{\text {hitung }}$ dan tabel 8 menunjukkan nilai $t_{\text {hitung. }}$.

Tabel 6. Ringkasan Hasil Uji Korelasi $X_{1}$ dan $X_{2}$ terhadap $Y$

Model Summary

\begin{tabular}{lcccc}
\hline Model & $R$ & $R$ Square & $\begin{array}{c}\text { Adjusted } R \\
\text { Square }\end{array}$ & $\begin{array}{c}\text { Std. Error of } \\
\text { the Estimate }\end{array}$ \\
\hline 1 & 0,492 & 0,242 & 0,218 & 9,818 \\
\hline
\end{tabular}

Sumber: Data primer yang diolah

Tabel 7. Ringkasan Hasil Uji F untuk Pengujian Pengaruh Simultan $X_{1}$ dan $X_{2}$ terhadap $Y$

$A N O V A^{\mathrm{b}}$

\begin{tabular}{|c|c|c|c|c|c|c|}
\hline Model & & $\begin{array}{c}\text { Sum of } \\
\text { Squares }\end{array}$ & $d f$ & Mean Square & $F$ & Sig. \\
\hline \multirow[t]{3}{*}{1} & Regression & 1970,703 & 2 & 985,351 & 10,223 & 0,000 \\
\hline & Residual & 6168,969 & 64 & 96,390 & & \\
\hline & Total & 8139,672 & 66 & & & \\
\hline
\end{tabular}

Sumber: Data primer yang diolah 
Tabel 8. Ringkasan Hasil Uji t untuk Pengujian Pengaruh $\mathrm{X}_{1}$ terhadap $\mathrm{Y}$ dan Pengaruh $\mathrm{X}_{2}$ terhadap $\mathrm{Y}$

Coefficients

\begin{tabular}{|c|c|c|c|c|c|c|c|c|}
\hline \multirow[b]{2}{*}{ Model } & \multicolumn{2}{|c|}{$\begin{array}{c}\text { Unstandardized } \\
\text { Coefficients }\end{array}$} & \multirow{2}{*}{$\begin{array}{c}\text { Standardized } \\
\text { Coefficients } \\
\text { Beta }\end{array}$} & \multirow[b]{2}{*}{$t$} & \multirow[b]{2}{*}{ Sig. } & \multicolumn{3}{|c|}{ Correlations } \\
\hline & $B$ & Std. Error & & & & $\begin{array}{l}\text { Zero- } \\
\text { order }\end{array}$ & Partial & Part \\
\hline 1 (Constant $)$ & $-9,451$ & 19,520 & & $-0,484$ & 0,630 & & & \\
\hline Sikap Peserta Didik & 0,346 & 0,191 & 0,273 & 1,815 & 0,074 & 0,454 & 0,221 & 0,197 \\
\hline Komitmen Diri Peserta Didik & 0,721 & 0,412 & 0,263 & 1,749 & 0,085 & 0,451 & 0,214 & 0,190 \\
\hline
\end{tabular}

Correlations

Sumber: Data primer yang diolah

Korelasi ganda yang menghubungkan persamaan vareiabel sikap peserta didik pada pelajaran matematika, komitmen diri peserta didik pada pelajaran matematika, dan prestasi belajar matematika peserta didik diperoleh dari tabel 6 . Berdasarkan tabel 6, diperoleh hasil korelasi sikap dan komitmen diri peserta didik secara bersama-sama dengan prestasi belajar matematika adalah 0,492; yang berarti korelasi antara ketiga variabel tersebut tergolong sedang. Koefisien determinasinya sebesar 0,242 atau ada kontribusi sebesar $24,2 \%$ berupa pengaruh sikap dan komitmen diri secara bersama-sama terhadap prestasi belajar matematika. Pengujian signifikansi korelasi menggunakan koefisien sig pada tabel 7 , dimana nilai sig $=0,000$; yang artinya korelasi antara ketiga variabel tersebut signifikan atau regresi ganda signifikan.

Selanjutnya adalah pengujian hipotesis regresi ganda $\mathrm{X}_{1}$ dan $\mathrm{X}_{2}$ terhadap $\mathrm{Y}$ dengan uji F. Adapun kriteria pengujiannya adalah $\mathrm{H}_{0}$ diterima jika $\mathrm{F}_{\text {hitung }}<\mathrm{F}_{\text {tabel }} \underline{\text { atau }} \mathrm{H}_{0}$ ditolak jika $F_{\text {hitung }}>F_{\text {tabel. }}$. Setelah dilakukan perhitungan, diperoleh nilai $\mathrm{F}$ seperti pada tabel 7. Berdasarkan tabel 7, diperoleh nilai $F_{\text {hitung }}=10,223$. Adapun dengan $\mathrm{dk}_{1}=2$ dan $\mathrm{dk}_{2}=64$ diperoleh nilai $F_{\text {tabel }}=3,140$. Oleh karena $\mathrm{F}_{\text {hitung }}>\mathrm{F}_{\text {tabel }}$ maka $\mathrm{H}_{0}$ ditolak. Hal ini berarti bahwa $\mathrm{H}_{0}$ (hipotesis nol) yang menyatakan terdapat pengaruh yang tidak signifikan sikap dan komitmen diri peserta didik secara bersama-sama terhadap prestasi belajar matematika adalah ditolak. Dengan demikian, hipotesis pada penelitian ini yang berbunyi: "terdapat pengaruh yang signifikan sikap dan komitmen diri peserta didik secara bersama-sama terhadap prestasi belajar matematika" adalah diterima. Dengan kata lain, dapat disimpulkan bahwa terdapat pengaruh yang signifikan sikap dan komitmen diri peserta didik secara bersama-sama terhadap prestasi belajar matematika.

Adapun persamaan regresi ganda yang diperoleh berdasarkan hasil penelitian ini dapat disusun berdasarkan tabel 8. Berdasarkan tabel 8, dapat disusun persamaan regresi ganda $\widehat{\mathbf{Y}}=-9,451+0,346 \mathbf{X}_{\mathbf{1}}+0,721 \mathbf{X}_{\mathbf{2}}$.

Adapun persamaan regresi ganda tersebut dapat diinterpretasikan sebagai berikut: Konstanta sebesar $-9,451$ menyatakan bahwa jika tidak ada sikap dan komitmen diri peserta didik pada pelajaran matematika maka prestasi belajar matematika peserta didik diperoleh sebesar 9,451. Atau dengan kata lain prestasi belajar matematika peserta didik diperoleh sebesar 9,451 manakala sikap dan komitmen diri peserta didik pada pelajaran matematika secara bersama-sama diabaikan. Dengan demikian, hasil perhitungan ini, sikap dan komitmen diri memberi pengaruh. 
Koefisien regresi $\mathbf{X}_{\mathbf{1}}$ (sikap peserta didik pada pelajaran matematika) sebesar 0,346 menyatakan bahwa setiap penambahan 1 satuan, sikap peserta didik pada pelajaran matematika akan meningkatkan prestasi belajar matematika sebesar 0,346 dengan anggapan $\mathbf{X}_{\mathbf{2}}$ (komitmen diri peserta didik pada pelajaran matematika) tetap. Berlaku juga sebaliknya, jika sikap peserta didik pada pelajaran matematika turun 1 satuan, maka prestasi belajar matematika diprediksi mengalami penurunan sebesar 0,346 dengan anggapan $\mathbf{X}_{\mathbf{2}}$ (komitmen diri peserta didik pada pelajaran matematika) tetap.

Koefisien regresi $\mathbf{X}_{\mathbf{2}}$ (komitmen diri peserta didik pada pelajaran matematika) sebesar 0,721 menyatakan bahwa setiap penambahan 1 satuan, komitmen diri peserta didik pada pelajaran matematika akan meningkatkan prestasi belajar matematika sebesar 0,721 dengan anggapan $\mathbf{X}_{\mathbf{1}}$ (sikap peserta didik pada pelajaran matematika) tetap. Berlaku juga sebaliknya jika komitmen diri peserta didik pada pelajaran matematika turun 1 satuan, maka prestasi belajar matematika diprediksi mengalami penurunan sebesar 0,721 dengan anggapan $\mathbf{X}_{\mathbf{1}}$ (sikap peserta didik pada pelajaran matematika) tetap.

Kemudian nilai $\mathbf{t}$ seperti tampak pada tabel 8 , yang mana diperoleh nilai $\mathbf{t}_{\text {hitung sebesar 1,815. Pada taraf }}$ signifikansi 0,05 dengan $d k=\mathrm{n}-\mathrm{k}-$ $1=67-2-1=64$ diperoleh $\mathbf{t}_{\text {tabel }}=$ 1,997. Dengan demikian $\mathrm{H}_{0}$ diterima karena nilai $t_{\text {hitung }}<t_{\text {tabel }}(1,815<$ 1,997), hal ini berarti terdapat pengaruh yang tidak signifikan sikap peserta didik pada pelajaran matematika terhadap prestasi belajar matematika. Dengan kata lain, secara parsial sikap peserta didik pada pelajaran matematika berpengaruh tidak signifikan.
Berikutnya tertera pada tabel 8 , nilai $\mathbf{t}_{\text {hitung }}$ sebesar 1,749 . Pada taraf signifikansi 0,05 dengan $d k=\mathrm{n}-\mathrm{k}-$ $1=130-2-1=64$ diperoleh nilai $\mathbf{t}_{\text {tabel }}=1$ 1,997. Dengan demikian $\mathrm{H}_{0}$ diterima karena nilai $t_{\text {hitung }}<t_{\text {tabel }}$ $(1,749<1,997)$, hal ini berarti terdapat pengaruh yang tidak signifikan komitmen diri peserta didik pada pelajaran matematika terhadap prestasi belajar matematika. Dengan kata lain, secara parsial komitmen diri peserta didik pada pelajaran matematika berpengaruh tidak signifikan terhadap prestasi belajar matematika.

\section{Pembahasan Hasil Penelitian}

1. Pengaruh Simultan Sikap dan Komitmen Diri Peserta Didik terhadap Prestasi Belajar Matematika Berdasarkan pada perhitungan data hasil penelitian menunjukkan bahwa terdapat pengaruh yang signifikan sikap dan komitmen diri peserta didik terhadap prestasi belajar matematika. Terlihat dari hasil perhitungan menunjukkan persamaan regresi ganda yang terbangun pada penelitian ini adalah $\widehat{\mathbf{Y}}=-9,451+0,346 \mathbf{X}_{1}+0,721 \mathbf{X}_{\mathbf{2}}$, artinya konstanta sebesar $-9,451$ menyatakan bahwa jika tidak ada sikap dan komitmen diri peserta didik, maka prestasi belajar matematika peserta didik diperoleh sebesar 9,451. Atau dengan kata lain, prestasi belajar matematika peserta didik diperoleh sebesar 9,451 manakala sikap dan komitmen diri peserta didik secara bersama-sama diabaikan. Kemudian penjelasan lain merujuk pada hasil perhitungan juga menunjukkan besarnya kontribusi sikap peserta didik pada pelajaran matematika $\left(\mathrm{X}_{1}\right)$ dan komitmen diri peserta didik pada pelajaran matematika $\left(\mathrm{X}_{2}\right)$ secara bersamasama terhadap prestasi belajar 
matematika (Y) adalah 24,2\%, artinya untuk $100 \%$ prestasi belajar matematika yang diraih oleh peserta didik, variabel sikap dan komitmen diri peserta didik secara bersamasama memberi kontribusi sebesar $24,2 \%$, sisanya dipengaruhi oleh faktor lain yang tidak dibahas dalam penelitian ini.

Sikap peserta didik pada pelajaran matematika, yang dalam hal ini berupa kesadaran opini atau pendapat peserta didik secara sadar merasakan manfaat dan kegunaan mengikuti pelajaran matematika, berupa emosional atau perasaan suka dan tidak suka atas kegiatan belajar matematika, dan berupa niat untuk berperilaku dalam cara tertentu terhadap hal-hal yang berkaitan dengan kegiatan belajar matematika manakala dipadukan secara bersamasama dengan komitmen diri peserta didik pada pelajaran matematika akan memberi dampak positif dan berpengaruh secara signifikan terhadap prestasi belajar matematika yang diraih. Adapun komitmen diri peserta didik pada pelajaran matematika yang dimaksud dalam penelitian ini, diantaranya berupa komitmen terhadap tugas untuk mengikuti dan melaksanakan kegiatan belajar matematika. Secara spesifik, hal-hal yang dimaksud antara lain: peserta didik mampu mengidentifikasi masalah tentang tugas mata pelajaran matematika yang sedang dihadapi, peserta didik mampu menentukan pilihan penyelesaian atas berbagai tugas mata pelajaran matematika yang sedang dihadapi, dan peserta didik mampu menentukan standar atas berhasil atau gagalnya dalam hal menghadapi dan menyelesaikan berbagai tugas pada mata pelajaran matematika.
2. Pengaruh Sikap Peserta Didik pada Pelajaran Matematika terhadap Prestasi Belajar Matematika

Berdasarkan pada perhitungan data hasil penelitian menunjukkan bahwa terdapat pengaruh yang tidak signifikan sikap peserta didik pada pelajaran matematika terhadap prestasi belajar matematika. Hasil perhitungan menunjukkan bahwa nilai $t_{\text {hitung }}<t_{\text {tabel }}$ yaitu $1,815<$ 1,997. Kemudian diketahui besarnya kontribusi sikap peserta didik pada pelajaran matematika terhadap prestasi belajar matematika adalah 12,4\%. Terlihat dari tabel 8 , nilai standar koefisien beta untuk sikap adalah 0,273 dan nilai zero order untuk sikap adalah 0,454. Jika koefisien beta dikali dengan zero order, maka diperoleh 0,124 . Hal ini berarti $12,4 \%$ sebagai besarnya kontribusi secara parsial sikap peserta didik pada pelajaran matematika terhadap prestasi belajar matematika.

Seperti yang sudah diketahui, besarnya kontribusi sikap dan komitmen diri peserta didik secara bersama-sama sebesar $24,2 \%$, artinya untuk $100 \%$ prestasi belajar matematika yang diraih oleh peserta didik, sikap dan komitmen diri secara bersama-sama memberi kontribusi sebesar $24,2 \%$, sisanya dipengaruhi oleh faktor lain yang tidak dibahas dalam penelitian ini. Diketahui dari kontribusi bersama-sama sebesar $24,2 \%$ ini, kontribusi sikap peserta didik pada pelajaran matematika $\left(\mathrm{X}_{1}\right)$ terhadap prestasi belajar matematika (Y) adalah 12,4\%. Secara lebih sederhana, dapat difahami bahwa secara kontribusi bersama-sama sikap dan komitmen diri sebesar 24,2\% dan secara parsial hanya sikap saja, ternyata besarnya kontribusi sebesar $12,4 \%$. 
3. Pengaruh Komitmen Diri Peserta Didik terhadap Prestasi Belajar Matematika

Berdasarkan pada perhitungan data hasil penelitian menunjukkan bahwa terdapat pengaruh yang tidak signifikan komitmen diri peserta didik pada pelajaran matematika terhadap prestasi belajar matematika. Hasil perhitungan menunjukkan bahwa nilai $t_{\text {hitung }}<t_{\text {tabel }}$ yaitu $1,749<1,997$. Kemudian diketahui besarnya kontribusi komitmen diri peserta didik pada pelajaran matematika terhadap prestasi belajar matematika adalah $11,8 \%$. Terlihat dari tabel 8, nilai standar koefisien beta untuk komitmen diri adalah 0,263 dan nilai zero order untuk sikap adalah 0,451. Jika koefisien beta dikali dengan zero order, maka diperoleh 0,118. Hal ini berarti $11,8 \%$ sebagai besarnya kontribusi secara parsial komitmen diri peserta didik pada pelajaran matematika terhadap prestasi belajar matematika.

Seperti yang sudah diketahui, besarnya kontribusi sikap dan komitmen diri peserta didik secara bersama-sama sebesar $24,2 \%$, artinya untuk $100 \%$ prestasi belajar matematika yang diraih oleh peserta didik, sikap dan komitmen diri secara bersama-sama memberi kontribusi sebesar $24,2 \%$, sisanya dipengaruhi oleh faktor lain yang tidak dibahas dalam penelitian ini. Diketahui dari kontribusi bersama-sama sebesar $24,2 \%$ ini, kontribusi komitmen diri peserta didik pada pelajaran matematika $\left(\mathrm{X}_{2}\right)$ terhadap prestasi belajar matematika (Y) adalah $11,8 \%$. Secara lebih sederhana, dapat difahami bahwa secara kontribusi bersama-sama sikap dan komitmen diri sebesar 24,2\% dan secara parsial hanya komitmen diri saja, besarnya kontribusi sebesar 11,8\%.
Task dalam kamus bahasa inggris berarti "tugas" sedangkan commitment berarti tanggung jawab. Secara bahasa task commitment dapat diartikan tanggung jawab terhadap tugas. Tanggung jawab terhadap tugas adalah suatu bentuk halus dari motivasi. Akbar dan Hawadi (2002: 67) menyatakan bahwa, "jika motivasi biasanya didefinisikan sebagai suatu proses energi umum yang merupakan faktor pemicu pada organisme, tanggung jawab energi tersebut ditampilkan pada tugas tertentu pada spesifik". Faktor-faktor yang memengaruhi task commitment (komitmen terhadap tugas) menurut Dimyati dan Mudjiono (2006: 97) sebagai berikut: (a) Cita-cita atau aspirasi siswa; (b) Kemampuan siswa; (c) Kondisi siswa; (d) Kondisi lingkungan; (e) Unsur-unsur dinamis dalam belajar dan pembelajaran; dan (f) Upaya guru dalam membelajarkan siswa. Menurut Akbar dan Hawadi (2002: 92), ciri-ciri perilaku task commitment diantaranya:

1. Tekun menghadapi tugas (dapat bekerja terus menerus untuk waktu lama, tidak berhenti sebelum selesai);

2. Ulet (tidak lekas putus asa bila menghadapi kesulitan);

3. Mampu berprestasi sendiri tanpa dorongan orang lain;

4. Ingin mendalami bahan atau bidang pengetahuan yang diberikan di dalam kelas (ingin mengetahui banyak bahan dari sekedar diajarkan oleh guru);

5. Selalu berusaha untuk berprestasi sebaik mungkin (tidak cepat puas denga prestasinya);

6. Menunjukkan minat terhadap bermacam-macam masalah orang dewasa (misalnya terhadap pembangunan agama, politik, ekonomi, korupsi, dan keadilan); 
7. Senang dan rajin belajar dengan penuh semangat;

8. Cepat bosan dengan tugas-tugas rutin (dalam pelajaran maupun pekerjaan);

9. Dapat mempertahankan pendapatnya (kalau sudah yakin dengan sesuatu, tidak mudah melepaskan pendapat tersebut);

10. Menunda pemuasan kebutuhan sesaat untuk mencapai tujuan di kemudian hari (misalnya: siswa membatasi waktu bermain untuk mencapai prestasi yang lebih tinggi).

\section{SIMPULAN DAN SARAN}

\section{Simpulan}

Berdasarkan data hasil penelitian dan analisis perhitungan data yang sudah dilakukan pada peserta didik kelas VII di Panglima Besar Soedirman International Islamic Junior High School (PBS-IIJHS), diperoleh simpulan hasil penelitian terdapat pengaruh yang signifikan sikap dan komitmen diri peserta didik secara bersama-sama terhadap prestasi belajar matematika, dengan kontribusi sebesar $24,2 \%$. Kemudian secara parsial terdapat pengaruh yang tidak signifikan sikap peserta didik terhadap prestasi belajar matematika, dengan kontribusi sebesar $12,4 \%$; dan juga secara parsial terdapat pengaruh yang tidak signifikan komitmen diri peserta didik terhadap prestasi belajar matematika, dengan kontribusi sebesar $11,8 \%$.

\section{Saran}

Berdasarkan rangkaian penelitian yang sudah dilaksanakan, melalui hasil penelitian ini, peneliti menaruh harapan tinggi untuk sistem pendidikan di Indonesia dapat terus membaik secara dinamis dari waktu ke waktu. Selain itu juga, peneliti berharap agar berbagai pihak di lingkungan pendidikan secara proaktif dapat merujuk pada berbagai hasil penelitian. Melalui hasil penelitian ini, peneliti menyampaikan beberapa saran, antara lain bagi para peneliti lain yaitu dapat melaksanakan kajian penelitian yang sama, namun subjek penelitian berbeda. Hal ini dimaksudkan untuk lebih menegaskan lagi seperti apa konseptual yang mesti dibangun guna meningkatkan kualitas pendidikan, khususnya prestasi belajar matematika.

Saran lain peneliti sampaikan pada peserta didik, hendaknya terjaga untuk membangun sikap dan komitmen diri, khususnya pada mata pelajaran matematika. Dengan begitu, besar kemungkinan peserta didik dapat meraih prestasi belajar matematika yang jauh lebih baik. Bagi sekolah, diharapkan dapat membangun sistem berupa peraturan tegas berkaitan dengan sikap dan komitmen diri peserta didik sehingga secara otomatis peserta didik dapat mematuhi aturan tersebut dengan sungguh-sungguh. Bagi guru dalam kegiatan pembelajaran seyogyanya sadar untuk menjadi ujung tombak, dimana guru hendaknya dapat memberikan kesadaran untuk peserta didik akan pentingnya sikap dan komitmen diri agar peserta didik tidak melalaikan tanggung jawabnya. Guru juga diharapkan dapat sungguh-sungguh menjadi contoh teladan bagi peserta didik untuk dapat bersikap baik pada pelajaran matematika dan membangun komitmen diri yang kuat pada diri peserta didik dalam mengikuti pembelajaran matematika. Kemudian orangtua sebagai sosok utama dalam terlaksananya pendidikan informal, seyogyanya mampu menanamkan berbagai perilaku sikap positif dan membangun pondasi yang kokoh untuk komitmen diri anak-anaknya. 


\section{DAFTAR RUJUKAN}

Akbar, R. dan Hawadi. (2002). Identifikasi Keberbakatan Intelektual Melalui Metode Non-Tes. Jakarta: Grasindo.

Baiquni, A. 2016. Siswa Madrasah Jakarta Juara Olimpiade Matematika Dunia. Diakses pada 31 Agustus 2016, dari http://www.m.dream.co.id.

Dimyati \& Mudjiono. (2006). Belajar dan Pembelajaran. Jakarta: Rineka Cipta.

Hakim, A. R. 2015. Analisis Prestasi Belajar Matematika Ditinjau dari Kecerdasan Spiritual dan Sikap Peserta Didik pada Pelajaran Matematika. Prosiding SNPM Unindra 2015. Jakarta: Unindra Press.

Hartati, L. 2013. Pengaruh Gaya Belajar dan Sikap Peserta didik pada Pelajaran Matematika terhadap Hasil Belajar Matematika. Formatif, 3 (3): 224-235.

Karim, A. 2014. Pengaruh Gaya Belajar dan Sikap Peserta didik pada Pelajaran Matematika terhadap Kemampuan Berpikir Kritis Matematika. Formatif, 4 (3): 188-195.

Metropolis. 2016. Raih Medali Emas Kompetisi Matematika International. Diakses pada 31 Agustus 2016, dari http://www.pontianakpost.co.id.

Pusat Pembinaan dan Pengembangan Bahasa. 2005. Pedoman Umum Ejaan Bahasa Indonesia yang Disempurnakan. Jakarta: Balai Pustaka.

Puspitasari, S. N. 2016. Indonesia Raih Emas di Olimpiade Matematika. Diakses pada 31 Agustus 2016, dari http://www.pikiran-rakyat.com.

Riduwan. 2005. Belajar Mudah Penelitian untuk Guru, Karyawan dan Peneliti Pemula. Bandung: Alfabeta.

Robbins, S. P. Dan Jugde, T. A. 2008. Perilaku Organisasi: Organizatinal Behavior. Jakarta: Salemba Empat.

Rosa, N. M. 2012. Pengaruh Sikap pada Mata Pelajaran Kimia dan Konsep Diri terhadap Prestasi Belajar Kimia. Formatif, 2 (3): 218-226.

Ruhiyat, Y. 2011. Pengaruh Konsep Diri dan Sikap Peserta Didik pada Matematika terhadap Prestasi Belajar Matematika Kelas X SMA (Survei pada Peserta didik Gugus 01 SMA di Kota Tangerang Selatan). Jakarta: Universitas Indraprasta PGRI.

Sujianto, A. E. 2009. Aplikasi Statistik dengan SPSS 16.0. Jakarta: Prestasi Pustaka Publisher.

Undang-undang Republik Indonesia Nomor 20 Tahun 2003 tentang Sistem Pendidikan Nasional. Yogyakarta: Media Wacana.

Walgito, B. 2005. Pengantar Psikologi Umum. Yogyakarta: Andi Offset.

Winkel, W. S. 1996. Psikologi Pendidikan dan Evaluasi Pendidikan. Jakarta: Gramedia. 